\title{
Solitary Pulmonary Nodule Malignancy Predictive Models Applicable to Routine Clinical Practice: A Systematic Review
}

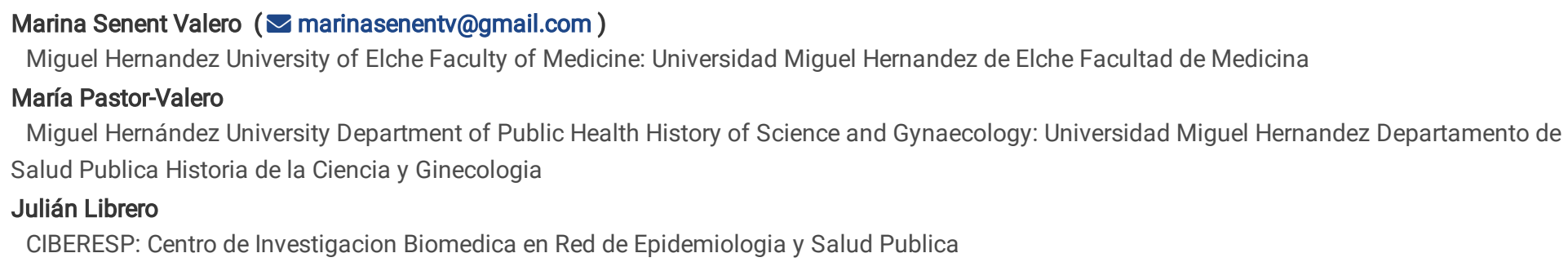




\section{Abstract}

Background: Solitary Pulmonary Nodule (SPN) is a common finding in routine clinical practice when performing chest imaging tests. The vast majority of these nodules are benign, and only a small proportion are malignant. Facing clinical experience as a guide for decision-making in the management of SPN, the application of predictive models of malignancy in routine clinical practice would help to achieve better diagnostic management of SPN. For this, it is necessary to know and evaluate the current state of knowledge in relation to predictive models of malignancy of SPN in the general or low-risk population. The present systematic review was carried out with the purpose of critically assess studies aimed at developing predictive models of Solitary Pulmonary Nodule (SPN) malignancy from SPN incidentally detected in routine clinical practice.

Methods: we performed a systematic review through the following bibliographic databases: MEDLINE, SCOPUS and Cochrane Library. We used The Transparent Reporting of a multivariable Prediction model for Individual Prognosis Or Diagnosis (TRIPOD) statement to describe the type of predictive model included in each study. We used The Prediction model Risk Of Bias ASsessment Tool (PROBAST) to evaluate the quality of the selected articles. The Fleischner guidelines for the management of incidental SPN were used as reference to describe the variables included in the models.

Results: 186 references were retrieved and after applying the exclusion/inclusion criteria, 15 articles remained for the final review. All studies analysed clinical and radiological variables. The most frequent independent predictors of malignancy included in the models were, in order of frequency: age, diameter, spiculated edge of the SPN, calcification, and smoking history. Variables such as race, growth rate of the SPN, emphysema, fibrosis, apical scarring and exposure to asbestos, uranium and radon among others were not analysed by the majority of the studies. All studies were classified as high risk of bias due to inadequate study designs, selection bias, insufficient follow-up of the population, and lack of external validation, compromising their applicability for clinical practice.

Conclusions: The studies included have been shown to have methodological weaknesses compromising the clinical applicability of the evaluated SPN malignancy predictive models and their potential influence on clinical decision-making for the SPN diagnostic management.

Systematic review registration: PROSPERO International prospective register of systematic reviews: CRD42020161559.

\section{Background}

Solitary Pulmonary Nodule (SPN), defined as pulmonary opacity up to $30 \mathrm{~mm}$ in diameter, is a common finding in routine clinical practice when performing chest imaging tests such as radiographs or computed tomography for any reason. $(1,2)$ The vast majority of these nodules are benign, and only a small proportion (around $10 \%-20 \%$ ) are malignant.(3,4) In a recent cohort study in Spain, after 5 years of follow-up, a prevalence of malignancy of SPN, incidentally detected by chest radiography or Computed Tomography (CT), of $12.1 \%$ and $18.2 \%$ respectively, was observed(5). With the inclusion of CT as a diagnostic test in routine clinical practice, the incidental finding of SPN has increased significantly, leading to the generation of new clinical practice guidelines for its diagnostic management.(1,6-8) The Fleischner guidelines $(6,7)$ are based on an exhaustive review of the literature and expert opinion on the diagnostic management of SPN incidentally found on lung CT in patients $\geq 35$ years, excluding the high-risk population (screening), immunocompromised or current cancer (of any type) patients.

This guide ${ }^{7}$ uses the probability of pre-test malignancy based on individual characteristics of the nodule and the patient, to determine the duration of radiological follow-up. Although nodule size and morphology (higher risk of spiculate edge versus regular edge), remain the dominant factors to predict the risk of SPN malignancy, the Fleischner guidelines consider other additional risk factors such as consistency of the nodule (higher risk in subsolid nodules compared to solid), nodule growth rate, nodule location, higher risk in upper lobes, smokers of $\geq 30$ pack-years, exposure to carcinogens (asbestos, uranium and radon), emphysema and/or pulmonary fibrosis, and/or apical scar, family history of lung cancer, over 40 years of age, race (individuals of African descent and Hawaiians being more at risk) and sex (with a higher risk in women with subsolid nodules). Its main recommendations are: follow-up with CT at 3 months, Positron Emission Tomography-Computed Tomography (PET-CT) or biopsy in solid nodules $>8 \mathrm{~mm}$ and high-risk patients, for subsolid nodules of $>6 \mathrm{~mm}$ follow-up with CT at 3-6 months for part-solid nodules or 6-12 months follow-up for SPN in ground glass. Routine follow-up is recommended in low-risk patients and SPN $<6 \mathrm{~mm}$.

Adherence to these guidelines is considered very important to decrease both over evaluation (prolonged surveillance, multiple biopsies, unnecessary radiation and surgery, etc.) and under evaluation (diagnostic delay). However, compliance with these in routine clinical practice is far from optimal. Studies in the United States reveal breaches ranging from $39 \%$ to $73 \% .(4,9,10)$ In Spain, a significant overvaluation of $72 \%$ of the SPN detected by chest radiography was observed, and $61.5 \%$ of those detected by CT.(2)

Despite the existence of guidelines for the diagnostic management of SPN, when an SPN appears incidentally in routine clinical practice, clinicians tend to adopt a proactive attitude. The key question here is knowing the cancer risk of the SPN detected in the course of routine clinical care - not in a screening setting. For this, it is essential to know and determine the thresholds, conditioned by the characteristics of the patient and the nodule, as a basis to support the decision to continue with additional diagnostic procedures or maintain active surveillance. 
Over the years, multivariate predictive models have been designed that are mathematical equations that combine and relate multiple predictors of a particular individual to obtain a pre-test risk/probability of the future presence or occurrence of a particular result.(11) Most predictive models of malignancy of an SPN arise from high-risk populations, with very strict inclusion criteria that therefore render them difficult to extrapolate to usual clinical populations. An exception is the model by McWilliams et al(12), the "Brock model", that despite being built from a high-risk population (screening), has been externally validated in a routine clinical practice population and has been shown to be equally valid.(13)

Facing clinical intuition/experience as a guide for decision-making in the management of SPN, the application of predictive models of malignancy in routine clinical practice would help to achieve better diagnostic management of SPN. For this, it is necessary to know and evaluate the current state of knowledge in relation to predictive models of malignancy of SPN in the general or low-risk population. In the absence of systematic reviews, the present review was carried out with the purpose of critically analysing studies that have constructed predictive models of malignancy of SPNs found incidentally in routine clinic settings to be applicable in standard clinic contexts.

\section{Material And Methods Design}

A systematic review of studies for the construction of predictive models of malignancy of SPN applicable in routine clinic settings. The study protocol was registered with the University of York Centre for Reviews and Dissemination International prospective register of systematic reviews (PROSPERO Record CRD42020161559, http://www.crd.york.ac.uk/PROSPERO/).

\section{Source of data collection}

We performed a search for scientific articles from the first available date in the following databases until October 2020: MEDLINE (via PubMed), SCOPUS and Cochrane Library. The final search equation was developed for use in MEDLINE, adapting it to the rest of the databases consulted, leaving the following: ("solitary pulmonary nodule" [MeSH Terms] OR ("solitary" [All Fields] AND "pulmonary" [All Fields ] AND "nodule" [All Fields]) OR "solitary pulmonary nodule" [All Fields]) AND (prediction [All Fields] AND model [All Fields]) AND (("lung" [MeSH Terms] OR "lung" [All Fields] OR "pulmonary" [All Fields]) AND ("neoplasms" [MeSH Terms] OR "neoplasms" [All Fields] OR "malignancy" [All Fields])). This was completed with a strategy based on the snowball principle.

\section{Selection of articles}

Inclusion criteria: observational studies carried out in the general population, who are at least 35 years old, in a hospital setting complying with the study objective: construction of predictive models of malignancy of pulmonary solitary nodule detected incidentally in routine clinical practice, studies published in peer-reviewed journals, in Spanish, Portuguese or English. Exclusion criteria: non-human studies, screening for lung cancer, metastatic nodules, models based on computational approaches (such as radiomics) and non-empirical analysis tools were excluded. The selection of articles was carried out independently by 2 authors (MSV, \& MPV). We prioritized sensibility over specificity in the selection of the articles. Possible discordance was resolved by consulting a third author (JL) and subsequently consensus among all authors was reached. The interobserver variability was calculated using the Cohen's kappa coefficient (K).

\section{Data extraction}

The studies in this review were described considering the following data: first reference author and year of publication, where the study and followup were carried out, type of study, characteristics of the population, number of participants, prevalence of malignancy, prevalence of former smokers or active smokers, statistical analysis and predictor variables (Table 1).

In Table 2 we present the clinical and radiological variables of the 15 predictive models evaluated. These were described according to the recommendations of the Fleischner guidelines 2017(7).The clinical characteristics included: sex, race, emphysema, fibrosis, apical scarring, multiplicity and perifissural nodules; the radiological characteristics included: nodule size, growth rate, morphology, consistency, and location. For SPN Growth Rate the Volume Doubling Time (1 VDT is equivalent to a $26 \%$ increase in diameter) is recommended, being in the $100-400$-day range for the majority of solid cancers and on the order of 3-5 years for subsolid cancerous nodules.

Appendices A and B show the external validations; those carried out by the authors themselves and by other authors, respectively. In turn, Appendix A describes the results of applying models developed by other authors to the same sample. Furthermore, in both Appendices we use the Transparent Reporting of a multivariable Prediction model for Individual Prognosis Or Diagnosis (TRIPOD) statement(14) to describe the type of predictive model included in each study included in our review, as well as the results of the discrimination and the calibration of these.

Finally, in Appendix $\mathrm{C}$ we describe the predictive mathematical models of each study evaluated. 


\section{Quality of research}

The Prediction model Risk Of Bias ASsessment Tool (PROBAST) was used to assess the quality of the selected articles(11), with the aim of providing a structured judgment of the risk of bias, thereby allowing the analysis of the applicability and transferability of predictive models to clinical practice. It contains 20 items on potential biases distributed in 4 domains/dimensions (participants, predictors, results, and analysis). Applicability is analysed for participants, predictor, and outcome domains. The response templates for each model are reflected in Appendix D.

In Table 3, as in Figure 1 and Figure 2, following the table format suggested by PROBAST(11), we have presented the quality results, representing the Risk of Bias, the Applicability and the final global assessment, respectively.

\section{Results}

Using the described search criteria, 186 references were identified (56 Scopus, 130 PubMed), of which 51 duplicates were removed. On evaluating the Abstract and title, 104 articles were eliminated and the inter-observer reliability, Cohen's kappa coefficient, was 0.75 (the authors agreed over the inclusion of 26 articles, excluding 97 and disagreed over 12, of which they eventually accepted 5 and rejected 7 as a result of subsequent consensus among the 3 authors). We retrieved and analysed a final sample of 31 full-text articles. The inter-observer kappa coefficient was 0.87 (the authors agreed over the inclusion of 15 articles and the exclusion of 14, and disagreed over 2 , finally rejecting both as a result of subsequent consensus among the 3 authors), leaving 15 articles in the final review (Figure 3). The quality evaluation of the studies was carried out in pairs in the same way as the selection of the articles with a kappa coefficient $>80 \%$ ". The topicality of the articles was calculated using the Burton-Kebler semi-period, which showed that the references had a median age of 5 years, and the Price Index, which showed that $67 \%$ of documents were less than 5 years old.

The main characteristics of the studies are shown in Table 1. All were retrospective studies, 2 were carried out in the USA, 11 in China and Japan, 1 in Portugal and1 in Spain. The largest sample size was that of Dong et al(15), with a cohort of 1679 subjects, and the smallest that of van Gómez López et al(16) with 55. In all studies, the study population were patients diagnosed with an SPN for the first time in routine clinic settings, in 3 from an imaging test (X-ray or CT/PET-CT of the chest), and in 12 from those sent to surgery/biopsy for histopathological diagnosis. In most studies the exclusion criteria were: previous history of cancer in the last 5 years or fewer, diagnosis of lung cancer or metastasis, and incomplete patient data. In 5 studies(17-21) participants with a previous history of cancer in the past 5 years were excluded, one(15) excluded those in just the previous year, and two excluded patients with history of cancer but did not specify the time period $(22,23)$.

All studies analysed clinical and radiological variables, also including biomarkers in 6 studies $(15,18,20,21,24,25)$. The prevalence of malignancy of the nodules ranged from $23 \%$ to $77.45 \%$ and that of current or past smokers ranged from $19 \%$ to $91 \%$ in benign nodules, and from $22.3 \%$ to $97 \%$ in malignant nodules.

Table 2 shows that all the models evaluated included risk factors such as sex, age, and the diameter of the SPN. All studies included the morphology and location of the SPN except one(16) and all studies included smoking habits except two(24,26). Only one study(17) included exposure to asbestos, none included exposure to radon or uranium, and only one(23) included passive exposure to tobacco smoke. Emphysema was collected in 2 studies $(21,24)$, and family history of lung cancer was collected in only one(21). Only one study(23) described perifissural nodules, and two studies $(23,26)$ included multiple nodules. Race, growth rate of the nodule, fibrosis and apical scarring were not reported in any of the studies.

In relation to nodule consistency, the majority of the studies $n=(8)$ did not specify the nodule consistency $(15-19,22,25,27)$ whereas the other 7 studies included this information: 1 study reported subsolid nodules(23), 2 studies collected patients with only solid nodules (21,24), and 4 $(23,26,28,29)$ included both (solid and subsolid nodules). However, only $1(23)$ of the 7 studies analysed the predictive risk of nodule consistency and found that mixed ground-glass nodules showed a higher risk of malignancy compared to solid nodules.

All studies in the review included individuals of both sexes $(1: 1)$, except two $(16,27)$ in which the male sex predominated and one $(23)$ in which the female sex predominated. The mean age of patients with benign nodules ranged from 48 to 62 years, and that of patients with malignant nodules ranged from 50 to 68 years. Previous cancer history was present in 11 articles(15,17,29,18,19,21,24-28). and ranged from $1.7 \%$ to $13.9 \%$.

Finally, the independent predictors of malignancy of SPN that were identified most frequently in the models were: age $(n=13)$, SPN diameter $(n=9)$, edge spiculation $(n=8)$, nodule calcification $(n=7)$ and smoking history $(n=6)$. Also found, among others, were: defined edge of the nodule $(n=4)$, lobulation of the nodule $(n=4)$, previous history of cancer $(n=4)$, and the Carcinoembryonic Antigen $(C E A)$ biomarker $(n=3)$.

In Appendix A, according to the TRIPOD classification(14), four studies were type $1 \mathrm{a}(16,23,26,29)$, one study was type $1 \mathrm{~b}(27)$, 5 were type $2 \mathrm{a}(15,17,20,22,24)$ and 5 were type $3(18,19,21,25,28)$. The sample size of the validations ranged from 120 to 344 participants. The discrimination of the models ranged from $0.599(27)$ to $0.910(25)$. Only 1 of the 15 models was calibrated(21), with a calibration of 0.928 .

In Appendix B, according to the TRIPOD classification(14), the 17 studies were type 4. Validations were carried out in the USA(30-34), Asia (China, Japan, Korea)(35-40), one in the United Kingdom(41), one in Brazil(42), one in the Netherlands(43), another in Italy(44), and in 2 it was not

Page $4 / 20$ 
specified(45,46). The prevalence of malignancy ranged from $25 \%$ to $85.6 \%$, with one study not providing this information, and the prevalence of current or past smokers ranged from $11.8 \%$ to $89 \%$, although this was not reported in 4 studies $(39,40,42,46)$. The size of the validations ranged from 86 to 702 participants. The Area Under the Curve (AUC) of all the models ranged from 0.53 to 0.89 . Only 5(31,33,34,37,43) of the 17 studies estimated the calibration of the models, 2 of these models $(17,19)$ underestimated the probability of malignancy; while another model(27) underestimated in 2 studies(31,37) and overestimated in one(34).

It should be noted that only $3(17,19,27)$ of the 15 studies included were validated by other authors, with Swensen et al(17) being the most validated model.

\section{Assessment of methodological quality}

The models risk of bias was assessed using the PROBAST tool(11) (Table 3, Figure, 1 \& 2). Regarding the Participants dimension, only 3 of the 15 studies were rated as appropriate by PROBAST, as case-control studies nested in a cohort $(17,27,29)$. The rest were non-nested case-control studies $(15,16,18,19,21,23-26)$; in $3(20,22,28)$ the type of study was not clear. Only two studies $(17,29)$ included all patients in routine clinical practice; the other studies selected those who underwent surgery/biopsy or who had suspected malignancy. Regarding the Predictors dimension, the possibility in any study of the result of malignancy being known prior to evaluation as recommended by PROBAST could not be ruled out; only one(18) specified that the results were unknown. Furthermore, in one study(27) predictors were not evaluated similarly because radiographs were studied by different radiologists. Regarding the Results dimension, the method of determining malignancy (surgery, biopsy or follow-up) was not adequate in 8 studies $(15,16,18,19,21-23,26)$, and was ambiguously estimated in $5(20,24,25,27,28)$, only being correct in two(17,29). None reported whether the measurement of the results was performed without the predictors analysed being known. Furthermore, the time interval between the evaluation of the variables and obtaining the result was not adequate in 3 studies $(17,27,29)$, in the rest it is unknown. Regarding the Analysis dimension, only 8 presented an adequate number of participants providing relevant results $(18,28)$ or an adequate number of events per variable $(15,16,23,24,27,29)$, as 3 could not be specified due to lack of data(17,20,22) or inadequate data in $3(19,21,25)$. In 5 studies(20-22,26,28) continuous variables were categorized/ dichotomized, and in only one(21) were data imputation techniques used for missing values.

Discrimination (AUC) and calibration (using the calibration slope \pm Hosmer-Lemeshow test) were evaluated in 5 studies(17,21,22,24,27) , while in 4 others $(15,18,23,25)$ only the calibration (Hosmer-Lemeshow test) was evaluated; and in the rest $(16,19,20,26,28,29)$ only discrimination was evaluated. Only in 2(21,24) were bootstrapping techniques used to avoid overestimation of the model. In 8 of the 15 models(15-17,19,21,22,27) the predictor weights of the models were assigned according to the results obtained from the multivariate analysis; of the rest, in 3 it was not clear due to lack of information $(18,28,29)$ and it was not correct in 4 others due to errors in the mathematical equation(20) and because the assigned weights did not coincide with the multivariate analysis $(23,24,26)$ (see Appendix C).

All studies were classified with a high risk of bias compromising their applicability (Figure 2).

\section{Discussion}

Our systematic review describes and evaluate published predictive models of Solitary Pulmonary Nodule (SPN) malignancy built from SPN incidentally encountered in routine clinical practice. The findings of this study showed that, there is an increasing scientific interest on developing new predictive models, $67 \%$ of the articles publication date was less than 5 years old, however, the design of the predictive models assessed showed important methodological deficiencies which compromises their clinical applicability. To describe the models, we followed The Fleischner Society recommendations(7) for management of incidentally found solitary pulmonary nodules (solid or subsolid). To evaluate the applicability and transferability of the predictive models to clinical practice we used the PROBAST tool(11).

To our knowledge, this is the first systematic review of studies that develop predictive models of SPN malignancy in routine clinical practice, with $73 \%$ of them (11/15) performed in Asian populations. A recent prospective study of a multiethnic cohort corroborated that Native Hawaiians and African Americans have twice the excess risk of developing lung cancer, with a low number of cigarettes consumed, compared to Japanese Americans and Latinos(47), however, in this review we did not find studies on predictive models based on Hawaiians or African Americans. Moreover, the Fleischner guidelines(7) consider race to be a risk factor for SPN malignancy; but this risk factor was not included in any of the models reviewed.

Age, followed by the size of the nodule (diameter) were the most frequently identified independent predictors in 13 studies and 9 respectively. This is in line with the scientific evidence ${ }^{6,7}$ showing that, with increased age and SPN diameter, the risk of malignancy also increases.

Fleischner recommendations(7) on nodule size are to use the average diameter as the average of long-and short-axis diameters, both of which should be obtained on the same transverse, coronal, or sagittal reconstructed image, which more accurately reflects three-dimensional tumor volume. Of the 15 models only 4 described how the nodule diameter was measured. Thus, 3 studies $(16,23,29)$ only reported that the images of the nodule were acquired in 3-D dimensional mode, and 1(23) that the long and short axes of the nodules were measured, and the ratio of the short to long axis was calculated. Nodule diameter was not identified as an independent predictor risk factor of SPN malignancy in any of these studies.

Page 5/20 
As regards sex, differences have been observed in the clinical management of SPNs, with diagnostic delays identified, leading to a therapeutic delay, and greater radiation in women.(48) In our review, all studies included a female population, and in one(20) the predictive model with the highest proportion of ground glass $(\geq 50 \%)$ identified being a woman as an independent predictor.

As regards morphology, SPN spiculation appears as a frequent predictor in almost all studies(15,17-19,21,24,25,28), with lobulation also being significant, as a final predictor of SPN malignancy in 4 studies $(15,20,28,29)$.

Regarding calcification, central/lamellar/diffuse/popcorn calcifications suggest benignity, while dotted patterns/eccentric localization suggest malignancy. Calcification was predictive in 7 models $(15,18-20,22,24,28)$. However, as the calcification pattern was not taken into account, nodules with calcification indicating benign characteristics were treated in the same manner as if the pattern suggested malignancy, possibly creating bias in terms of the prediction of malignancy.

Although smoking is considered the highest risk criterion, it was only identified as a predictor in 6 of the models(15,17,22,25,27,28) . In the rest $(16,18-21,23,24,26,29)$ it was perhaps not identified because the proportion of smokers/ex-smokers was low and the malignant SPNs showed a greater proportion of adenocarcinomas, a histological pattern that is less related to this exposure.

The previous history of any type of cancer in family members was collected in 6 studies $(15,19,20,24,25,29)$ and was identified as a malignancy predictor in 2(15,19). Furthermore, the previous personal history of cancer was collected in 11 studies $(15,17,29,18,19,21,24-28)$ and in 4 of the models $(17,24,26,28)$ it was found to be a predictive factor of malignancy. Despite genetic susceptibility has been described previously, concluding that there is an association between a previous history of cancer in first-degree relatives, and increased risk of lung cancer in both sexes, (49) only one study (21) evaluated previous history of lung cancer in relatives and found that it was not a predictor of malignancy.

Some models found that CEA $(15,18,24)$ and CYFRA $21-1(15,25)$ biomarkers were final predictors of malignancy; however, none of the studies performed external validations, nor do the Fleischner guidelines include them as risk factors for malignancy. Further studies are required to assess their future importance in routine clinical practice

Exposure to other carcinogens (asbestos, uranium, radon) has been described as a risk factor for lung cancer(7)'(50). However, only one study collected exposure to asbestos(17) but did not identify it as a predictor. Although passive exposed to tobacco is one of the causes of lung cancer and it has been shown that $40 \%$ of children, $33 \%$ of non-smoking men and $35 \%$ of non-smoking women are exposed worldwide(51), only one study(23) analysed it and it was not found that passive exposure to tobacco smoke was an independent predictor of malignancy.

According to Fleischner guidelines, lung cancers occur more frequently in the upper lobes. However, although all studies collected the nodule location, only one study conducted in the USA(17) identified it as an independent predictor. In China, there are a high prevalence of tuberculosis and other granulomatous diseases, typically located in the upper lobes. Most of the studies in this review were involved the Asian population, without a relationship between nodule location and malignancy being observed.

Finally emphysema, considered as a risk factor(7), was identified in 2 articles(21,24), although neither was predictive. Chronic Obstructive Pulmonary Disease (COPD) was evaluated in a single study(21) but was not identified as a predictor. In another study(28), a final predictor was the history of chronic lung disease, but the type of disease was not specified. A recent meta-analysis confirms that this comorbidity is frequent in patients with lung cancer, and that both this and emphysema increase the level of risk, especially in smokers with heavy tobacco use.(52)

\section{Assessment of the Prediction Model Risk of Bias}

We will follow the PROBAST guidelines on potential biases distributed in 4 domains (participants, predictors, results, and analysis) to set out several methodological deficiencies of the studies included.(11)

There is clear disagreement between the prevalence of SPN malignancy found in the models included in this review (between $23 \%$ and $77.45 \%$ ) and the prevalence in daily clinical practice (between 12.1 and 18.2\%)(5). This is probably due to the fact that most models are based on the population referred for surgery/biopsy, with consequent selection bias, since there is an important group of the population attended to in routine clinic settings - those considered to be at lower risk of malignancy and less likely to be sent to surgery/biopsy - not included in most of the models studied. This selection bias occurs in all the studies except three $(17,27,29)$, which used a case-control design nested in a cohort study, also including those that only required radiological follow-up. The rest describe themselves as retrospective cohort studies $(15,16,18,19,21,23-26)$, and in three the type of study is not well established(20,22,28).

According to PROBAST(11), the prospective cohort study is considered the optimal design(11) with low risk of bias, since it allows all the information on the potential predictors (exposures) to be collected before the potential outcome, thus reducing selection or interviewer biases. Nonnested case-control studies in a cohort select a population from a study designed for another purpose, and therefore have a higher risk of bias. In line with the results obtained by Collins et al(53), the models are seldom prospective and usually use information from populations intended for a completely different purpose.

Page 6/20 
Nodule consistency (solid, subsolid) is a determining factor when predicting SPN malignancy. The stability of solid nodules is estimated over a period of 2 years(6,7), whereas in subsolids it is 5 years(7). Thus, longer initial follow-up intervals and longer total follow-up periods are

recommended for subsolid nodules than for solid nodules. Bearing this in mind, this was insufficient in the 3 studies that followed up(17,27,29) with a 2 years of follow up, respectively. The remaining studies ${ }^{15,16,18-25,27,29,}$ did not specify whether they followed up.

In some models there was categorization of continuous variables: in one(21) the values of the biomarkers were dichotomized; in others it was the smoking history ( $\geq 30$ pack-years)(28), ( $\geq 400$ pieces-year)(20); and in one it was the age ( $\geq 70$ years)(26). This establishes an arbitrary cut-off point, from which a different risk level is established, causing loss of information, so that predictive capacity is lost.(11)

In most of the studies the analysis does not mention patients with missing data. These are interpreted as having been omitted, meaning that the analysis performed is an "available/complete case analysis". This is the most frequent type of analysis in predictive models, and is the one which we suppose was in 14 of the 15 studies in which this information was not reported. The exclusion of missing data leads to biases in the association of the predictors with the result, and skews the performance of the model because after the exclusion of cases with incomplete information, the selected subpopulation may not be representative of the population. Only one study(21) took into account the missing data, and used the multiple imputation technique as recommended by PROBAST, with a lower risk of bias, and is considered the best method described.(11)

The optimal sample size for binary prediction models is considered to be a minimum of 100 events (preferably $\geq 200)$ for external validations(53), with 10-15 Events Per Variable (EPV) (better $\geq 20$ )(54) for development models.(11) This was the case in only 8 studies(15,16,18,23,24,27-29).

The external validation of any development model in an independent sample is essential to demonstrate its satisfactory performance, i.e., applicability and transferability in clinical practice. One of the most important limitations of the models created so far is the lack of external validations. External authors have only validated 3 models $(17,19,27)$ (Appendix B), the most frequently evaluated being that of Swensen et al(17), which has presented good discrimination in all of them, with values greater than $0.75(55)$. Although there are studies that have created models and have externally validated them with very promising results $(18,21,25)$, there are no studies as yet that corroborate the results obtained.

In some studies $(15,18,23,25)$ the Hosmer-Lemeshow Test was the only calibration method used. However, it is not without limitations: large sample sizes can generate erroneous results and it does not reveal the magnitude of the difference between the predicted values and the observed values(55). This does not happen with the calibration slope (the method most recommended by PROBAST), which was performed in only 5 articles $(17,21,22,24,27)$.

The 15 models analysed showed low clinical applicability due to the high probability of bias. In normal practice, models that do not present selection biases are required, ones that reflect all possible malignancy risk profiles (from none to all), that may occur in a patient with an SPN found incidentally. Some models are not explicit in the exclusion of patients with a recent history of cancer (the last 5 years) $(16,24,25,27,28)$, possibly they are more likely to experience a tumour recurrence/metastasis, thus overestimating the predictive values. In other cases, only solid nodules are included $(21,24)$ and cannot be applied to patients with subsolid nodules, and vice versa. Other recommendations on predictors and their measurements are that they should be standard and applicable to the clinical setting; specifically, biomarkers may not always be available.

\section{Limitations And Strengths Of This Review}

The heterogeneity of the studies did not allow for a meta-analysis. Only studies in English, Spanish or Portuguese were included. These languages allow a wide coverage of more than $90 \%$ of articles in the literature, however, we discarded 6 articles written in other languages that could have been relevant.

Additionally, when we used the search equation, there were a large number of articles that were not ultimately relevant to the study objective. This may have been due to the lack of specific descriptors (MeSH), which meant that we had to use MEDLINE to search for Title and Abstract fields.

The final number was limited $(n=15)$ and most involved high-risk populations, which limits the extrapolation of the results from the models identified to routine clinic practice.

The strengths of this review are the rigorous use of standard tools of proven methodological quality to evaluate the proposed models, and the independent selection and review of the articles included their quality, with high concordance among researchers in a relevant area of knowledge, as reflected in the Burton-Kebler Index and the Price Index. We attempted to minimize bias in the review by adhering to a registered protocol and following the PRISMA statement(56).

\section{Conclusions}

Our results indicate that most of the predictive models were built mainly from retrospective cohort studies with poor levels of methodological quality, rendering their applicability in routine clinical practice difficult. 
Although there is scientific evidence on multiple factors which determine the risk of malignancy of a SPN, important factors were not considered by most of the studies, such as, nodule consistency, growth rate, race, emphysema, fibrosis, the exposure to asbestos, uranium, radon, or passive tobacco smoke, among others. Moreover, the evaluation of the studies included in this paper leads us to underline the importance of identifying the risk factors of malignancy of solitary pulmonary nodule in different populations.

Efforts should be channeled towards epidemiological studies with prospective designs, and roust methodology representing the general population that uses clinical services.

We believe that these results highlight key information for clinicians when deciding how to use these models to aid in the diagnostic and therapeutic management of solitary pulmonary nodules.

\section{Abbreviations}

SPN (Solitary Pulmonary Nodule), PROBAST (Prediction model Risk Of Bias ASsessment Tool), TRIPOD (Transparent Reporting of a multivariable Prediction model for Individual Prognosis Or Diagnosis), CT (Computed Tomography), PET (Positron emission Tomography), CEA

(Carcinoembryonic Antigen), COPD (Chronic Obstructive Pulmonary Disease); AUC (Area Under the Curve), EPV (Events Per Variable); VDT (Volume Doubling Time).

\section{Declarations}

\section{Ethics approval and consent to participate}

Not applicable.

\section{Consent for publication}

Consent gained from all authors for publication.

\section{Availability of data and material}

Not applicable.

\section{Competing interests}

The authors declare that they have no competing interests

\section{Funding}

This research did not receive any specific grant from funding agencies in the public, commercial, or not-for-profit sectors.

\section{Authors' Contributions}

Marina Senent-Valero and María Pastor-Valero conceived the study and performed the collection and assembly of data. All authors performed the analysis and interpretation. Marina Senent-Valero drafted the first manuscript. All authors provided intellectual contributions to the manuscript and critical revision. All authors approved the final version.

\section{Acknowledgements}

The authors are grateful to Professor Javier Sanz for helping in the bibliographic search.

\section{Author details}

${ }^{1}$ Department of Public Health, History of Science and Gynaecology, Faculty of Medicine, Miguel Hernández University, Sant Joan d'Alacant (Alicante - Spain). ${ }^{2}$ CIBER in Epidemiology and Public Health (CIBERESP), Madrid, Spain. ${ }^{3}$ Navarrabiomed, Complejo Hospitalario de Navarra, UPNA. ${ }^{4}$ Red de Investigación en Servicios de Salud en Enfermedades Crónicas (REDISSEC), Valencia, Spain.

\section{References}

1. Gould MK, Donington J, Lynch WR, Mazzone PJ, Midthun DE, Naidich DP, et al. Evaluation of individuals with pulmonary nodules: When is it lung cancer? Diagnosis and management of lung cancer, 3rd ed: American college of chest physicians evidence-based clinical practice 
guidelines. Chest [Internet]. 2013;143(5 SUPPL):e93S-e120S. Available from: http://dx.doi.org/10.1378/chest.12-2351

2. Lumbreras B, Vilar J, González-Álvarez I, Gómez-Sáez N, Domingo ML, Lorente MF, et al. The fate of patients with solitary pulmonary nodules: Clinical management and radiation exposure associated. PLoS One. 2016;11(7):1-14.

3. Alzahouri K, Velten M, Arveux P, Woronoff-Lemsi MC, Jolly D, Guillemin F. Management of SPN in France. Pathways for definitive diagnosis of solitary pulmonary nodule: A multicentre study in 18 French districts. BMC Cancer. 2008;8:1-9.

4. Wiener RS, Gould MK, Slatore CG, Fincke BG, Schwartz LM, Woloshin S. Resource use and guideline concordance in evaluation of pulmonary nodules for cancer: Too much and too little care. JAMA Intern Med. 2014;174(6):871-80.

5. Chilet-Rosell E, Parker LA, Hernández-Aguado I, Valero MP, Vilar J, González-Álvarez I, et al. The determinants of lung cancer after detecting a solitary pulmonary nodule are different in men and women, for both chest radiograph and CT. PLoS One. 2019;14(9):1-13.

6. MacMahon H, Austin JHM, Gamsu G, Herold CJ, Jett JR, Naidich DP, et al. Guidelines for management of small pulmonary nodules detected on CT scans: A statement from the Fleischner Society. Radiology. 2005;237(2):395-400.

7. Heber MacMahon, MB, David P. Naidich, MD Jin Mo Goo, MD, Kyung Soo Lee, MD, Ann N. C. Leung, MD John R. Mayo, MD Atul C. Mehta, MB, Yoshiharu Ohno, MD, Charles A. Powell, MD Mathias Prokop, MD, Geoffrey D. Rubin, MD Cornelia M. Schaefer-Prokop, MD, Willia M. Guidelines for Management of Incidental Pulmonary Nodules Detected on CT Images: From the Fleischner Society 2017. JAMA - J Am Med Assoc. 2018;320(21):2260-1.

8. Callister MEJ, Baldwin DR, Akram AR, Barnard S, Cane P, Draffan J, et al. British Thoracic Society guidelines for the investigation and management of pulmonary nodules: accredited by NICE. Thorax [Internet]. 2015 Aug;70(Suppl 2):ii1-54. Available from: https://thorax.bmj.com/content/70/Suppl_2/ii1

9. Eisenberg R, Bankier A, Boiselle P. Compliance with Fleischner Society Guidelines for Management of Small Lung. Radiology. 2010;255(2):21824.

10. Esmaili A, Munden RF, Mohammed TLH. Small pulmonary nodule management: A survey of the members of the society of thoracic radiology with comparison to the fleischner society guidelines. J Thorac Imaging. 2011;26(1):27-31.

11. Moons KGM, Wolff RF, Riley RD, Whiting PF, Westwood M, Collins GS, et al. PROBAST: A tool to assess risk of bias and applicability of prediction model studies: Explanation and elaboration. Ann Intern Med. 2019;170(1):W1-33.

12. McWilliams A, Tammemagi MC, Mayo JR, Roberts H, Liu G, Soghrati K, et al. Probability of cancer in pulmonary nodules detected on first screening CT. N Engl J Med. 2013;369(10):910-9.

13. Chung K, Mets OM, Gerke PK, Jacobs C, Den Harder AM, Scholten ET, et al. Brock malignancy risk calculator for pulmonary nodules: Validation outside a lung cancer screening population. Thorax. 2018;73(9):857-63.

14. Moons KGM, Altman DG, Reitsma JB, loannidis JPA, Macaskill P, Steyerberg EW, et al. Transparent reporting of a multivariable prediction model for individual prognosis or diagnosis (TRIPOD): Explanation and elaboration. Ann Intern Med. 2015;162(1):W1-73.

15. Dong J, Sun N, Li J, Liu Z, Zhang B, Chen Z, et al. Development and validation of clinical diagnostic models for the probability of malignancy in solitary pulmonary nodules. Thorac Cancer. 2014;5(2):162-8.

16. López O van G, Vicente AMG, Martínez AFH, Londoño GAJ, Caicedo CHV, Atance PL, et al. 18F-FDG-PET/CT in the assessment of pulmonary solitary nodules: Comparison of different analysis methods and risk variables in the prediction of malignancy. Transl Lung Cancer Res. 2015;4(3):228-35.

17. Swensen SJ. The Probability of Malignancy in Solitary Pulmonary Nodules. Arch Intern Med [Internet]. 1997 Apr 28;157(8):849. Available from: https://jamanetwork.com/journals/jamainternalmedicine/issue/157/8

18. Yonemori K, Tateishi U, Uno H, Yonemori Y, Tsuta K, Takeuchi M, et al. Development and validation of diagnostic prediction model for solitary pulmonary nodules. Respirology. 2007;12(6):856-62.

19. Li Y, Wang J. A mathematical model for predicting malignancy of solitary pulmonary nodules. World J Surg. 2012;36(4):830-5.

20. Zheng B, Zhou X, Chen J, Zheng W, Duan Q, Chen C. A Modified Model for Preoperatively Predicting Malignancy of Solitary Pulmonary Nodules: An Asia Cohort Study. Ann Thorac Surg [Internet]. 2015;100(1):288-94. Available from: http://dx.doi.org/10.1016/j.athoracsur.2015.03.071

21. Chen XB, Yan RY, Zhao K, Zhang DF, Li YJ, Wu L, et al. Nomogram for the prediction of malignancy in small (8-20 mm) indeterminate solid solitary pulmonary nodules in chinese populations. Cancer Manag Res. 2019;11:9439-48.

22. Wu Z, Huang T, Zhang S, Cheng D, Li W, Chen B. A prediction model to evaluate the pretest risk of malignancy in solitary pulmonary nodules: evidence from a large Chinese southwestern population. J Cancer Res Clin Oncol [Internet]. 2020;(37). Available from:

https://doi.org/10.1007/s00432-020-03408-2

23. Chen W, Zhu D, Chen H, Luo J, Fu H. Predictive model for the diagnosis of benign/malignant small pulmonary nodules. Medicine (Baltimore). 2020;99(15):e19452.

24. She Y, Zhao L, Dai C, Ren Y, Jiang G, Xie H, et al. Development and validation of a nomogram to estimate the pretest probability of cancer in Chinese patients with solid solitary pulmonary nodules: A multi-institutional study. J Surg Oncol. 2017;116(6):756-62. 
25. Zhang M, Zhuo N, Guo Z, Zhang X, Liang W, Zhao S, et al. Establishment of a mathematic model for predicting malignancy in solitary pulmonary nodules. J Thorac Dis. 2015;7(10):1833-41.

26. Jacob M, Romano J, Araújo D, Pereira JM, Ramos I, Hespanhol V. Predicting lung nodules malignancy. Pulmonology. 2020;(xx):1-7.

27. Gould MK, Ananth L, Barnett PG. A clinical model to estimate the pretest probability of lung cancer in patients with solitary pulmonary nodules. Chest [Internet]. 2007;131(2):383-8. Available from: http://dx.doi.org/10.1378/chest.06-1261

28. Yang L, Zhang Q, Bai L, Li TY, He C, Ma QL, et al. Assessment of the cancer risk factors of solitary pulmonary nodules. Oncotarget. 2017;8(17):29318-27.

29. Wang L, Chen Y, Tang K, Lin J, Zhang H. The Value of 18F-FDG PET/CT Mathematical Prediction Model in Diagnosis of Solitary Pulmonary Nodules. Biomed Res Int. 2018;2018.

30. Hammer MM, Nachiappan AC, Barbosa EJM. Limited Utility of Pulmonary Nodule Risk Calculators for Managing Large Nodules. Curr Probl Diagn Radiol [Internet]. 2018;47(1):23-7. Available from: http://dx.doi.org/10.1067/j.cpradiol.2017.04.003

31. Talwar A, Rahman NM, Kadir T, Pickup LC, Gleeson F. A retrospective validation study of three models to estimate the probability of malignancy in patients with small pulmonary nodules from a tertiary oncology follow-up centre. Clin Radiol [Internet]. 2017;72(2):177.e1-177.e8. Available from: http://dx.doi.org/10.1016/j.crad.2016.09.014

32. Tanner NT, Aggarwal J, Gould MK, Kearney P, Diette G, Vachani A, et al. Management of pulmonary nodules by community pulmonologists a multicenter observational study. Chest [Internet]. 2015;148(6):1405-14. Available from: http://dx.doi.org/10.1378/chest.15-0630

33. Isbell JM, Deppen S, Putnam JB, Nesbitt JC, Lambright ES, Dawes A, et al. Existing general population models inaccurately predict lung cancer risk in patients referred for surgical evaluation. Ann Thorac Surg [Internet]. 2011;91(1):227-33. Available from:

http://dx.doi.org/10.1016/j.athoracsur.2010.08.054

34. Schultz EM, Sanders GD, Trotter PR, Patz EF, Silvestri GA, Owens DK, et al. Validation of two models to estimate the probability of malignancy in patients with solitary pulmonary nodules. Thorax. 2008;63(4):335-41.

35. Xiao F, Liu D, Guo Y, Shi B, Song Z, Tian Y, et al. Novel and convenient method to evaluate the character of solitary pulmonary nodulecomparison of three mathematical prediction models and further stratification of risk factors. PLoS One. 2013;8(10):1-6.

36. Shinohara S, Hanagiri T, Takenaka M, Chikaishi Y, Oka S, Shimokawa H, et al. Evaluation of undiagnosed solitary lung nodules according to the probability of malignancy in the American College of Chest Physicians (ACCP) evidence-based clinical practice guidelines. Radiol Oncol. 2014;48(1):50-5.

37. Zhang X, Yan HH, Lin JT, Wu ZH, Liu J, Cao XW, et al. Comparison of three mathematical prediction models in patients with a solitary pulmonary nodule. Chinese J Cancer Res. 2014;26(6):647-52.

38. Yang B, Jhun BW, Shin SH, Jeong BH, Um SW, Zo J II, et al. Comparison of four models predicting the malignancy of pulmonary nodules: A single-center study of Korean adults. PLoS One. 2018;13(7):1-10.

39. Cui X, Heuvelmans MA, Han D, Zhao Y, Fan S, Zheng S, et al. Comparison of veterans affairs, Mayo, Brock classification models and radiologist diagnosis for classifying the malignancy of pulmonary nodules in Chinese clinical population. Transl Lung Cancer Res. 2019;8(5):605-13.

40. Li Y, Hu H, Wu Z, Yan G, Wu T, Liu S, et al. Evaluation of models for predicting the probability of malignancy in patients with pulmonary nodules. Biosci Rep. 2020;40(2):1-11.

41. Al-Ameri A, Malhotra P, Thygesen H, Plant PK, Vaidyanathan S, Karthik S, et al. Risk of malignancy in pulmonary nodules: A validation study of four prediction models. Lung Cancer [Internet]. 2015;89(1):27-30. Available from: http://dx.doi.org/10.1016/j.lungcan.2015.03.018

42. Cromwell Barbosa de Carvalho Melo, João Aléssio Juliano Perfeito, Danilo Félix Daud, Altair da Silva Costa Júnior, Ilka Ilka Lopes Santoro LEVL. Analysis and validation of probabilistic models for predicting malignancy in solitary pulmonary nodules in a population in Brazil. J Bras Pneumol. 2012;63(2):159-66.

43. Herder GJ, Van Tinteren H, Golding RP, Kostense PJ, Comans EF, Smit EF, et al. Clinical prediction model to characterize pulmonary nodules: Validation and added value of 18F-fluorodeoxyglucose positron emission tomography. Chest [Internet]. 2005;128(4):2490-6. Available from: http://dx.doi.org/10.1378/chest.128.4.2490

44. Soardi GA, Perandini S, Larici AR, del Ciello A, Rizzardi G, Solazzo A, et al. Multicentre external validation of the BIMC model for solid solitary pulmonary nodule malignancy prediction. Eur Radiol [Internet]. 2017;27(5):1929-33. Available from: http://dx.doi.org/10.1007/s00330-0164538-5

45. Perandini S, Soardi GA, Motton M, Dallaserra C, Montemezzi S. Limited value of logistic regression analysis in solid solitary pulmonary nodules characterization: A single-center experience on 288 consecutive cases. J Surg Oncol. 2014;110(7):883-7.

46. Perandini S, Soardi GA, Motton M, Rossi A, Signorini M, Montemezzi S. Solid pulmonary nodule risk assessment and decision analysis: comparison of four prediction models in 285 cases. Eur Radiol. 2015;26(9):3071-6.

47. Stram DO, Park SL, Haiman CA, Murphy SE, Patel Y, Hecht SS, et al. Racial/Ethnic Differences in Lung Cancer Incidence in the Multiethnic Cohort Study: An Update. J Natl Cancer Inst. 2019;111(8):811-9. 
48. Chilet-Rosell E, Parker LA, Hernández-Aguado I, Pastor-Valero M, Vilar J, González-Álvarez I, et al. Differences in the clinical management of women and men after detection of a solitary pulmonary nodule in clinical practice. Eur Radiol. 2020;

49. Yoshida K, Takizawa Y, Nishino Y, Takahashi S, Kanemura S, Omori J, et al. Association between family history of cancer and lung cancer risk among Japanese men and women. Tohoku J Exp Med. 2019;247(2):99-110.

50. Nielsen LS, Bælum J, Rasmussen J, Dahl S, Olsen KE, Albin M, et al. Occupational asbestos exposure and lung cancer - A systematic review of the literature. Arch Environ Occup Heal. 2014;69(4):191-206.

51. Öberg M, Jaakkola MS, Woodward A, Peruga A, Prüss-Ustün A. Worldwide burden of disease from exposure to second-hand smoke: A retrospective analysis of data from 192 countries. Lancet [Internet]. 2011;377(9760):139-46. Available from: http://dx.doi.org/10.1016/S01406736(10)61388-8

52. Mouronte-Roibás C, Leiro-Fernández V, Fernández-Villar A, Botana-Rial M, Ramos-Hernández C, Ruano-Ravina A. COPD, emphysema and the onset of lung cancer. A systematic review. Cancer Lett [Internet]. 2016;382(2):240-4. Available from: http://dx.doi.org/10.1016/j.canlet.2016.09.002

53. Collins GS, Ogundimu EO, Altman DG. Sample size considerations for the external validation of a multivariable prognostic model: A resampling study. Stat Med. 2016;35(2):214-26.

54. Núñez E, Steyerberg EW, Núñez J. Estrategias para la elaboración de modelos estadísticos de regresión. Rev Esp Cardiol. 2011;64(6):501-7.

55. Alba AC, Agoritsas T, Walsh M, Hanna S, lorio A, Devereaux PJ, et al. Discrimination and calibration of clinical prediction models: Users' guides to the medical literature. JAMA - J Am Med Assoc. 2017;318(14):1377-84.

56. Moher D, Liberati A, Tetzlaff J, Altman DG, Altman D, Antes G, et al. Preferred reporting items for systematic reviews and meta-analyses: The PRISMA statement. PLoS Med. 2009;6(7).

\section{Tables}

Table 1 Main characteristics of the studies included in the review 


\begin{tabular}{|c|c|c|c|c|c|c|c|c|}
\hline $\begin{array}{l}\text { Authors of } \\
\text { the models } \\
\text { (year of } \\
\text { publication) }\end{array}$ & $\begin{array}{l}\text { Location } \\
\text { and } \\
\text { follow- } \\
\text { up of the } \\
\text { study }\end{array}$ & $\begin{array}{l}\text { Type of } \\
\text { study }\end{array}$ & Study population & $\begin{array}{l}\text { Number } \\
\text { of } \\
\text { subjects }\end{array}$ & $\begin{array}{l}\text { Prevalence } \\
\text { of } \\
\text { malignancy } \\
(\%)\end{array}$ & $\begin{array}{l}\text { Prevalence } \\
\text { of current } \\
\text { or past } \\
\text { smokers } \\
\text { (\%) }\end{array}$ & $\begin{array}{l}\text { Statistical } \\
\text { methods }\end{array}$ & $\begin{array}{l}\text { Predictor } \\
\text { variables }\end{array}$ \\
\hline \multirow[t]{2}{*}{$\begin{array}{l}\text { M. Jacob et } \\
\text { al. (2020) } \\
(26)\end{array}$} & \multirow[t]{2}{*}{$\begin{array}{l}\text { Portugal, } \\
\text { NR }\end{array}$} & \multirow[t]{2}{*}{$\begin{array}{l}\text { Retrospective } \\
\text { cohort study }\end{array}$} & \multirow[t]{2}{*}{$\begin{array}{l}\text { Patients who underwent } \\
\text { percutaneous CT-guided } \\
\text { transthoracic biopsy. Only } \\
\text { cases where the biopsy } \\
\text { target was less than } 3 \mathrm{~cm} \\
\text { diameters in initial CT } \\
\text { evaluation were included. }\end{array}$} & 121 & $53 \%$ & $\begin{array}{l}\text { Benign } \\
\text { nodules: } \\
48 \% \\
\text { Malignant } \\
\text { nodules: } \\
51.9 \%\end{array}$ & $\begin{array}{l}\text { Logistic } \\
\text { regression } \\
\text { analysis }\end{array}$ & $\begin{array}{l}\text { Clinical/ } \\
\text { radiological } \\
\text { characteristics }\end{array}$ \\
\hline & & & & & & & & \\
\hline \multirow[t]{2}{*}{$\begin{array}{l}\text { Chen W et } \\
\text { al. }(2020) \\
(23)\end{array}$} & \multirow[t]{2}{*}{$\begin{array}{l}\text { China, } \\
\text { NR }\end{array}$} & \multirow[t]{2}{*}{$\begin{array}{l}\text { Retrospective } \\
\text { case-control } \\
\text { study }\end{array}$} & $\begin{array}{l}\text { Patients who had } \\
\text { undergone PN resection. } \\
\text { The inclusion criterion } \\
\text { was patients with PN of } \leq \\
10 \text { mm in size on } \\
\text { preoperative chest high- } \\
\text { resolution CT. }\end{array}$ & 216 & $74 \%$ & NR & $\begin{array}{l}\text { Logistic } \\
\text { regression } \\
\text { analysis }\end{array}$ & $\begin{array}{l}\text { Clinical/ } \\
\text { radiological } \\
\text { characteristics }\end{array}$ \\
\hline & & & $\begin{array}{l}\text { The exclusion criteria } \\
\text { were: } 10 \% \text { increase in } \\
\text { maximum diameter within } \\
3 \text { months; personal or } \\
\text { family history of cancer; } \\
\text { or lesions completely } \\
\text { calcified. }\end{array}$ & & & & & \\
\hline \multirow[t]{2}{*}{$\begin{array}{l}\text { Wu Z et al. } \\
(2020)(22)\end{array}$} & \multirow[t]{2}{*}{$\begin{array}{l}\text { China, } \\
\text { NR }\end{array}$} & \multirow[t]{2}{*}{$\begin{array}{l}\text { Retrospective } \\
\text { cohort study }\end{array}$} & $\begin{array}{l}\text { Patients with the } \\
\text { radiographic diagnosis of } \\
\text { SPNs. All diagnoses of } \\
\text { SPNs were pathologically } \\
\text { confirmed through } \\
\text { operation or biopsy. }\end{array}$ & 721 & NR & $\begin{array}{l}\text { Benign } \\
\text { nodules: } \\
19 \% \\
\text { Malignant } \\
\text { nodules: } \\
28 \%\end{array}$ & $\begin{array}{l}\text { Logistic } \\
\text { regression } \\
\text { analysis }\end{array}$ & $\begin{array}{l}\text { Clinical/ } \\
\text { radiological } \\
\text { characteristics }\end{array}$ \\
\hline & & & $\begin{array}{l}\text { Patients with multiple } \\
\text { nodules or history of lung } \\
\text { cancer or extrapulmonary } \\
\text { carcinoma were excluded. }\end{array}$ & & & & & \\
\hline \multirow[t]{2}{*}{$\begin{array}{l}\text { Chen et al. } \\
(2019)(21)\end{array}$} & \multirow[t]{2}{*}{$\begin{array}{l}\text { China, } \\
\text { NR }\end{array}$} & \multirow[t]{2}{*}{$\begin{array}{l}\text { Retrospective } \\
\text { cohort study }\end{array}$} & $\begin{array}{l}\text { Patients with SPNs who } \\
\text { underwent surgical } \\
\text { resection to confirm the } \\
\text { benignity /malignancy of } \\
\text { the nodule. }\end{array}$ & 493 & $43.4 \%$ & $\begin{array}{l}\text { Benign } \\
\text { nodules: } \\
34.05 \% \\
\text { Malignant } \\
\text { Nodules: } \\
33.18 \%\end{array}$ & $\begin{array}{l}\text { Logistic } \\
\text { regression } \\
\text { analysis }\end{array}$ & $\begin{array}{l}\text { Clinical/ } \\
\text { radiological } \\
\text { characteristics } \\
\text { and serum } \\
\text { biomarkers }\end{array}$ \\
\hline & & & $\begin{array}{l}\text { The exclusion criteria } \\
\text { were: patients with a } \\
\text { history of cancer ( } \leq 5 \\
\text { years ago), } \\
\text { immunocompromised } \\
\text { patients, PN with a } \\
\text { feeding artery and vein } \\
\text { typical, PN with } \\
\text { intranodular fat or } \\
\text { calcium content or } \\
\text { absence of the available } \\
\text { thin-slice }(1 \mathrm{~mm}) \text { images. }\end{array}$ & & & & & \\
\hline $\begin{array}{l}\text { Wang et al. } \\
(2018)(29)\end{array}$ & $\begin{array}{l}\text { China, } 2 \\
\text { years }\end{array}$ & $\begin{array}{l}\text { Retrospective } \\
\text { cohort study }\end{array}$ & $\begin{array}{l}\text { Patients who were } \\
\text { confirmed with SPNs and } \\
\text { had undergone PET/CT. } \\
\text { Malignant nodules were } \\
\text { confirmed by } \\
\text { histopathologic } \\
\text { examination of the tissue }\end{array}$ & 177 & $67.23 \%$ & NR & $\begin{array}{l}\text { Logistic } \\
\text { regression } \\
\text { analysis }\end{array}$ & $\begin{array}{l}\text { Clinical/ } \\
\text { radiological } \\
\text { characteristics }\end{array}$ \\
\hline
\end{tabular}


(continued)

Table 1 (Continued)

Page $13 / 20$ 


$\begin{array}{lll}\begin{array}{l}\text { Authors of } \\ \text { the models } \\ \text { (year of } \\ \text { publication) }\end{array} & \begin{array}{l}\text { Location } \\ \text { and } \\ \text { follow- }\end{array} & \begin{array}{l}\text { Type of } \\ \text { sp of } \\ \text { the } \\ \text { study }\end{array} \\ & & \\ & & \end{array}$

$\begin{array}{lll} & & \\ \text { She et al. } & \text { China, } & \text { Retrospective } \\ \text { cohort study }\end{array}$

$\begin{array}{lll}\text { Sumber } & \begin{array}{l}\text { Prevalence } \\ \text { of } \\ \text { subjects }\end{array} & \begin{array}{l}\text { of } \\ \text { malignancy } \\ (\%)\end{array}\end{array}$

Prevalence of

current or

past smokers

(\%)
Statistical methods

Predictor variables

obtained by

surgery or biopsy

and benign

nodules were

confirmed by

pathologic

diagnosis or

clinical follow-up.

Patients with the

longest diameter

of SPNs $<7 \mathrm{~mm}$,

a history of

primary lung

cancer, or related

thoracic surgery

with distant

metastasis were

excluded.

Patients with

benign/malignant

SPNs diagnosed

by thin-section CT

radiologically

confirmed by

surgery or biopsy.

899

$67.3 \%$

$19.7 \%$

Logistic

regression

Clinical/

regression
analysis

radiological

characteristics and serum biomarkers

Subsolid nodules

and any

indeterminate

nodule were

excluded.

$\begin{array}{lll}\text { Yang et al. } & \text { China, } & \begin{array}{l}\text { Retrospective } \\ \text { cohort study }\end{array} \\ (2017)(28) & \text { NR } & \end{array}$

Patients with

SPNs who

underwent CT-

guided needle

biopsy in their

hospital. All them

had biopsy

pathology results

of benign

/malignant

nodule.

$\begin{array}{ll}1078 \quad 66.88 \% & \text { Benign } \\ & \text { nodules: } \\ & 32.4 \% \\ & \text { Malignant } \\ & \text { nodules: } 40 \% \\ & \\ & \text { Indeterminate } \\ & \text { nodules: } \\ & 37.7 \%\end{array}$

Logistic

Clinical and

regression radiological

analysis characteristics

Malignant

nodules:

Patients with a

history of primary

lung cancer were

excluded.

$\begin{array}{lll}\text { Van Gómez } & \text { Spain, } & \text { Retrospective } \\ \text { López et al. } & \text { NR } & \text { cohort study }\end{array}$

Patients with a

SPN who

underwent a

combined whole-

body FDG

PET/CT imaging

and surgical

resection of the

SPN. A definitive

pathologic

diagnosis of the

SPN, classifying

the lesions as

benign or

malignant, was

established.

$\begin{array}{llll}55 & \text { N2.7\% } & \text { Logistic } & \text { Clinical/ } \\ \text { regression } & \text { radiological } \\ \text { analysis } & \text { characteristics }\end{array}$

Page $14 / 20$ 


\begin{tabular}{|c|c|c|c|c|c|c|c|c|}
\hline $\begin{array}{l}\text { Zheng et al. } \\
\text { (2015) (20) }\end{array}$ & $\begin{array}{l}\text { China, } \\
\text { NR }\end{array}$ & $\begin{array}{l}\text { Retrospective } \\
\text { cohort study }\end{array}$ & $\begin{array}{l}\text { Patients with } \\
\text { newly discovered } \\
\text { SPN found on } \\
\text { conventional } \\
\text { chest CT scans. } \\
\text { A definite } \\
\text { benign/malignant } \\
\text { diagnosis was } \\
\text { obtained based } \\
\text { on pathology } \\
\text { examination. } \\
\text { Patients who } \\
\text { were diagnosed } \\
\text { as having any } \\
\text { cancer within the } \\
\text { previous } 5 \text { years } \\
\text { were excluded, as } \\
\text { were those with a } \\
\text { history of primary } \\
\text { lung cancer or } \\
\text { with multiple } \\
\text { distant } \\
\text { metastases. }\end{array}$ & 846 & NR & $\begin{array}{l}\text { Benign } \\
\text { nodules: } \\
30.05 \% \\
\\
\text { Malignant } \\
\text { nodules: } \\
22.3 \%\end{array}$ & $\begin{array}{l}\text { Logistic } \\
\text { regression } \\
\text { analysis }\end{array}$ & $\begin{array}{l}\text { Clinical/radiological } \\
\text { characteristics and } \\
\text { serum biomarkers }\end{array}$ \\
\hline $\begin{array}{l}\text { Zhang et al. } \\
\text { (2015) (25) }\end{array}$ & $\begin{array}{l}\text { China, } \\
\text { NR }\end{array}$ & $\begin{array}{l}\text { Retrospective } \\
\text { cohort study }\end{array}$ & $\begin{array}{l}\text { Patients who } \\
\text { underwent } \\
\text { surgery /lung } \\
\text { resection for } \\
\text { histopathological } \\
\text { diagnosis }\end{array}$ & 294 & $59.9 \%$ & $\begin{array}{l}\text { Benign } \\
\text { nodules: } \\
31.4 \%\end{array}$ & $\begin{array}{l}\text { Logistic } \\
\text { regression }\end{array}$ & $\begin{array}{l}\text { Clinical/radiological } \\
\text { characteristics and }\end{array}$ \\
\hline
\end{tabular}

(continued)

Table 1 (Continued) 


\begin{tabular}{|c|c|c|c|c|c|c|c|c|}
\hline $\begin{array}{l}\text { Authors of } \\
\text { the models } \\
\text { (Year of } \\
\text { publication) }\end{array}$ & $\begin{array}{l}\text { Location } \\
\text { and } \\
\text { follow- } \\
\text { up of } \\
\text { the } \\
\text { study }\end{array}$ & $\begin{array}{l}\text { Type of } \\
\text { study }\end{array}$ & Study population & $\begin{array}{l}\text { Number } \\
\text { of } \\
\text { subjects }\end{array}$ & $\begin{array}{l}\text { Prevalence } \\
\text { of } \\
\text { malignancy } \\
(\%)\end{array}$ & $\begin{array}{l}\text { Prevalence } \\
\text { of current } \\
\text { or past } \\
\text { smokers } \\
\text { (\%) }\end{array}$ & $\begin{array}{l}\text { Statistical } \\
\text { methods }\end{array}$ & Predictor variables \\
\hline & & & of SPN. & & & Malignant & analysis & serum biomarkers \\
\hline & & & $\begin{array}{l}\text { An exclusion criteria } \\
\text { was incomplete } \\
\text { data. }\end{array}$ & & & $48.3 \%$ & & \\
\hline $\begin{array}{l}\text { Dong et al. } \\
\text { (2013) (15) }\end{array}$ & $\begin{array}{l}\text { China, } \\
\text { NR }\end{array}$ & $\begin{array}{l}\text { Retrospective } \\
\text { cohort study }\end{array}$ & $\begin{array}{l}\text { Patients with SPNs } \\
\text { diagnosed by chest } \\
\text { CT scans or X-ray } \\
\text { with a histological } \\
\text { diagnosis report as } \\
\text { a benign or } \\
\text { malignant nodule. }\end{array}$ & 1679 & $77.45 \%$ & $47 \%$ & $\begin{array}{l}\text { Logistic } \\
\text { regression } \\
\text { analysis }\end{array}$ & $\begin{array}{l}\text { Clinical/ } \\
\text { radiological } \\
\text { characteristics and } \\
\text { serum biomarkers }\end{array}$ \\
\hline & & & $\begin{array}{l}\text { Exclusion criteria } \\
\text { were: patients had } \\
\text { antineoplastic } \\
\text { therapy, } \\
\text { radiotherapy, or } \\
\text { chemotherapy prior } \\
\text { to surgery, cancer } \\
\text { diagnosis within one } \\
\text { year prior to the } \\
\text { operation for SPNs; } \\
\text { patients had } \\
\text { incomplete clinical } \\
\text { data; postoperative } \\
\text { histological } \\
\text { diagnosis of } \\
\text { patients was the } \\
\text { metastatic cancer of } \\
\text { extrapulmonary } \\
\text { organs. }\end{array}$ & & & & & \\
\hline $\begin{array}{l}\text { Li et al. } \\
\text { (2012) (19) }\end{array}$ & $\begin{array}{l}\text { China, } \\
\text { NR }\end{array}$ & $\begin{array}{l}\text { Retrospective } \\
\text { cohort study }\end{array}$ & $\begin{array}{l}\text { Patients who had a } \\
\text { solitary pulmonary } \\
\text { nodule resection to } \\
\text { obtain a } \\
\text { pathological } \\
\text { diagnosis of } \\
\text { benignity or } \\
\text { malignancy. }\end{array}$ & 371 & $61.7 \%$ & $\begin{array}{l}\text { Benign } \\
\text { nodules: } \\
32.4 \% \\
\text { Malignant } \\
\text { nodules: } \\
48 \%\end{array}$ & $\begin{array}{l}\text { Logistic } \\
\text { regression } \\
\text { analysis }\end{array}$ & $\begin{array}{l}\text { Clinical and } \\
\text { radiological } \\
\text { characteristics }\end{array}$ \\
\hline & & & $\begin{array}{l}\text { Patients were } \\
\text { excluded if they had } \\
\text { a history of } \\
\text { pulmonary or } \\
\text { extrapulmonary } \\
\text { malignancy in } 5 \\
\text { years or incomplete } \\
\text { data. }\end{array}$ & & & & & \\
\hline $\begin{array}{l}\text { Yonemori et } \\
\text { al. } \\
(2007)(18)\end{array}$ & $\begin{array}{l}\text { Japan, } \\
\text { NR }\end{array}$ & $\begin{array}{l}\text { Retrospective } \\
\text { cohort study }\end{array}$ & $\begin{array}{l}\text { Patients who } \\
\text { underwent surgery } \\
\text { for histopathological } \\
\text { diagnosis of SPN. }\end{array}$ & 452 & $75 \%$ & $\begin{array}{l}\text { Benign } \\
\text { nodules: } \\
47 \%\end{array}$ & $\begin{array}{l}\text { Logistic } \\
\text { regression } \\
\text { analysis }\end{array}$ & $\begin{array}{l}\text { Clinical/radiological } \\
\text { characteristics and } \\
\text { serum biomarkers }\end{array}$ \\
\hline & & & $\begin{array}{l}\text { Any SPN diagnosed } \\
\text { as metastatic } \\
\text { extrapulmonary } \\
\text { cancer or any cancer } \\
\text { within the past } 5 \\
\text { years was excluded. }\end{array}$ & & & $\begin{array}{l}\text { Malignant } \\
\text { nodules: } \\
54 \%\end{array}$ & & \\
\hline $\begin{array}{l}\text { Gould et al. } \\
\text { (2007) (27) }\end{array}$ & $\begin{array}{l}\text { USA, } 2 \\
\text { years }\end{array}$ & $\begin{array}{l}\text { Retrospective } \\
\text { cohort study }\end{array}$ & $\begin{array}{l}\text { Patients from } 10 \\
\text { geographically } \\
\text { diverse VA sites with }\end{array}$ & 375 & $54 \%$ & $\begin{array}{l}\text { Benign } \\
\text { nodules: } \\
91 \%\end{array}$ & $\begin{array}{l}\text { Logistic } \\
\text { regression } \\
\text { analysis }\end{array}$ & $\begin{array}{l}\text { Clinical and } \\
\text { radiological } \\
\text { characteristics }\end{array}$ \\
\hline
\end{tabular}




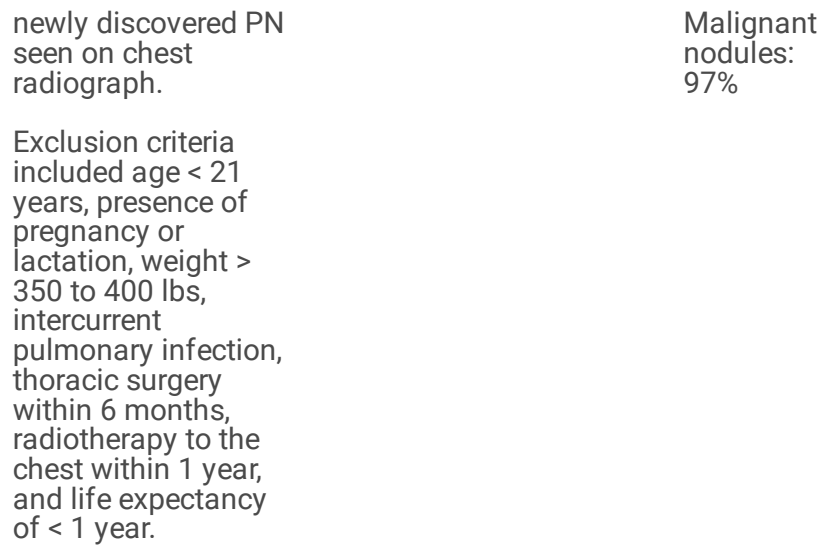

Exclusion criteria included age $<21$

years, presence of

pregnancy or

actation, weight >

350 to $400 \mathrm{lbs}$

intercurrent

pulmonary infection,

thoracic surgery

within 6 months,

radiotherapy to the

chest within 1 year,

and life expectancy

of $<1$ year.

(continued)

Table 1 (Continued)

\begin{tabular}{|c|c|c|c|c|c|c|c|c|}
\hline $\begin{array}{l}\text { Authors of } \\
\text { the models } \\
\text { (Year of } \\
\text { publication) }\end{array}$ & $\begin{array}{l}\text { Location } \\
\text { and } \\
\text { follow- } \\
\text { up of } \\
\text { the } \\
\text { study }\end{array}$ & $\begin{array}{l}\text { Type of } \\
\text { study }\end{array}$ & Study population & $\begin{array}{l}\text { Number } \\
\text { of } \\
\text { subjects }\end{array}$ & $\begin{array}{l}\text { Prevalence } \\
\text { of } \\
\text { malignancy } \\
(\%)\end{array}$ & $\begin{array}{l}\text { Prevalence of } \\
\text { current or } \\
\text { past smokers } \\
\text { (\%) }\end{array}$ & $\begin{array}{l}\text { Statistical } \\
\text { methods }\end{array}$ & $\begin{array}{l}\text { Predictor } \\
\text { variables }\end{array}$ \\
\hline & & & $\begin{array}{l}\text { They also excluded } \\
\text { participants who did } \\
\text { not have a qualifying } \\
\text { CT scan and/or did not } \\
\text { have a definitive } \\
\text { diagnosis of an SPN. } \\
\text { as malignant or benign } \\
\text { established. }\end{array}$ & & & & & \\
\hline $\begin{array}{l}\text { Swensen et } \\
\text { al. } \\
(1997)(17)\end{array}$ & $\begin{array}{l}\text { USA, } 2 \\
\text { years }\end{array}$ & $\begin{array}{l}\text { Retrospective } \\
\text { cohort study }\end{array}$ & $\begin{array}{l}\text { Patients with newly } \\
\text { discovered SPNs } \\
\text { detected by chest } \\
\text { radiograph or CT } \\
\text { scans. } \\
\\
\text { Patients who were } \\
\text { diagnosed as having } \\
\text { any cancer within the } \\
\text { past } 5 \text { years were } \\
\text { excluded. No patients } \\
\text { with clinical signs of } \\
\text { persistent or recurrent } \\
\text { malignant neoplasm or } \\
\text { with a history of } \\
\text { primary lung cancer } \\
\text { were included. }\end{array}$ & 629 & $23 \%$ & $\begin{array}{l}\text { Benign } \\
\text { nodules: } 61 \% \\
\text { Malignant } \\
\text { nodules: } 86 \% \\
\\
\text { Indeterminate } \\
\text { nodules: } 71 \%\end{array}$ & $\begin{array}{l}\text { Logistic } \\
\text { regression } \\
\text { analysis }\end{array}$ & $\begin{array}{l}\text { Clinical and } \\
\text { radiological } \\
\text { characteristics }\end{array}$ \\
\hline
\end{tabular}

Abbreviations: SPN, Solitary Pulmonary Nodule; PN, Pulmonary Nodule; VA, Veterans Affairs; Cm, centimetres; PET, Positron Emission Tomography; FDG PET/CT, F-fluorodeoxyglucose-Positron Emission Tomography/Computed Tomography; NR, Not Reported.

Due to technical limitations, table 2 is only available as a download in the Supplemental Files section.

Table 3 Quality of the models of the review according to PROBAST tool 


\begin{tabular}{|c|c|c|c|c|c|c|c|c|c|}
\hline \multirow{2}{*}{$\begin{array}{l}\text { Study, } \\
\text { year }\end{array}$} & \multicolumn{4}{|l|}{$\mathrm{ROB}^{\mathrm{a}}$} & \multicolumn{3}{|l|}{ Applicability ${ }^{b}$} & \multicolumn{2}{|c|}{ Overallc } \\
\hline & Participants & Predictors & Outcome & Analysis & Participants & Predictors & Outcome & ROB & Applicability \\
\hline Swensen et al., 1997 (17) & + & $?$ & - & - & + & $?$ & - & - & - \\
\hline $\begin{array}{l}\text { Gould et al., } \\
2007 \text { (27) }\end{array}$ & - & - & - & - & - & $?$ & - & - & - \\
\hline Yonemori et al., 2007 (18) & - & + & - & - & - & $?$ & - & - & - \\
\hline Li et al., 2012 (19) & - & $?$ & - & - & - & $?$ & - & - & - \\
\hline $\begin{array}{l}\text { Dong et al. } \\
2013(15)\end{array}$ & - & $?$ & - & - & - & $?$ & - & - & - \\
\hline $\begin{array}{l}\text { Zhang et al., } \\
2015 \text { (25) }\end{array}$ & - & $?$ & $?$ & - & - & $?$ & - & - & - \\
\hline $\begin{array}{l}\text { Zheng et al., } \\
2015 \text { (20) }\end{array}$ & - & $?$ & $?$ & - & - & $?$ & - & - & - \\
\hline $\begin{array}{l}\text { Van Gómez López et al., } \\
2015 \text { (16) }\end{array}$ & - & $?$ & - & - & - & $?$ & - & - & - \\
\hline $\begin{array}{l}\text { Yang et al., } \\
2017 \text { (28) }\end{array}$ & - & $?$ & $?$ & - & - & $?$ & - & - & - \\
\hline $\begin{array}{l}\text { She et al., } \\
2017 \text { (24) }\end{array}$ & - & $?$ & $?$ & - & - & $?$ & - & - & - \\
\hline Wang et al., 2018 (29) & - & $?$ & - & - & - & $?$ & - & - & - \\
\hline $\begin{array}{l}\text { Chen et al., } \\
2019 \text { (21) }\end{array}$ & - & $?$ & - & - & - & $?$ & - & - & - \\
\hline $\begin{array}{l}\text { Wu Z et al. } \\
(2020)(22)\end{array}$ & - & $?$ & - & . & - & $?$ & - & - & - \\
\hline Chen W et al. (2020) (23) & - & $?$ & - & - & - & $?$ & - & - & - \\
\hline $\begin{array}{l}\text { M. Jacob et al. } \\
(2020)(26)\end{array}$ & - & $?$ & - & - & - & $?$ & - & - & - \\
\hline
\end{tabular}

Notes: "+" indicates low ROB/low concern regarding applicability; "-" indicates high ROB/high concern regarding applicability; and "?" indicates unclear ROB/unclear concern regarding applicability. ${ }^{a}$ Obtaining each domain of Risk of Bias is established based on the responses of their respective items (Appendix D) as follows: if all items are answered with "Yes", the domain is at low risk of bias. If in at least one item the answer is "Unclear" and the rest of the items are "Yes", the risk of bias is unclear. If the answer is "No" in at least one item, independently of the other answers, the domain is at high risk of bias. ${ }^{b}$ The applicability of each domain is established by consensus among the authors. ${ }^{c}$ The final overall assessment is expressed as follows: low risk of bias if all domains have low risk of bias; high risk of bias in case at least one domain presents high risk of bias; if the risk is not clear in at least one domain and all the other domains are low risk of bias, the final assessment remains unclear. Ditto for applicability.

Abbreviations: PROBAST, Prediction model Risk Of Bias Assessment Tool; ROB, Risk Of Bias.

\section{Figures}




\section{Risk of Bias}

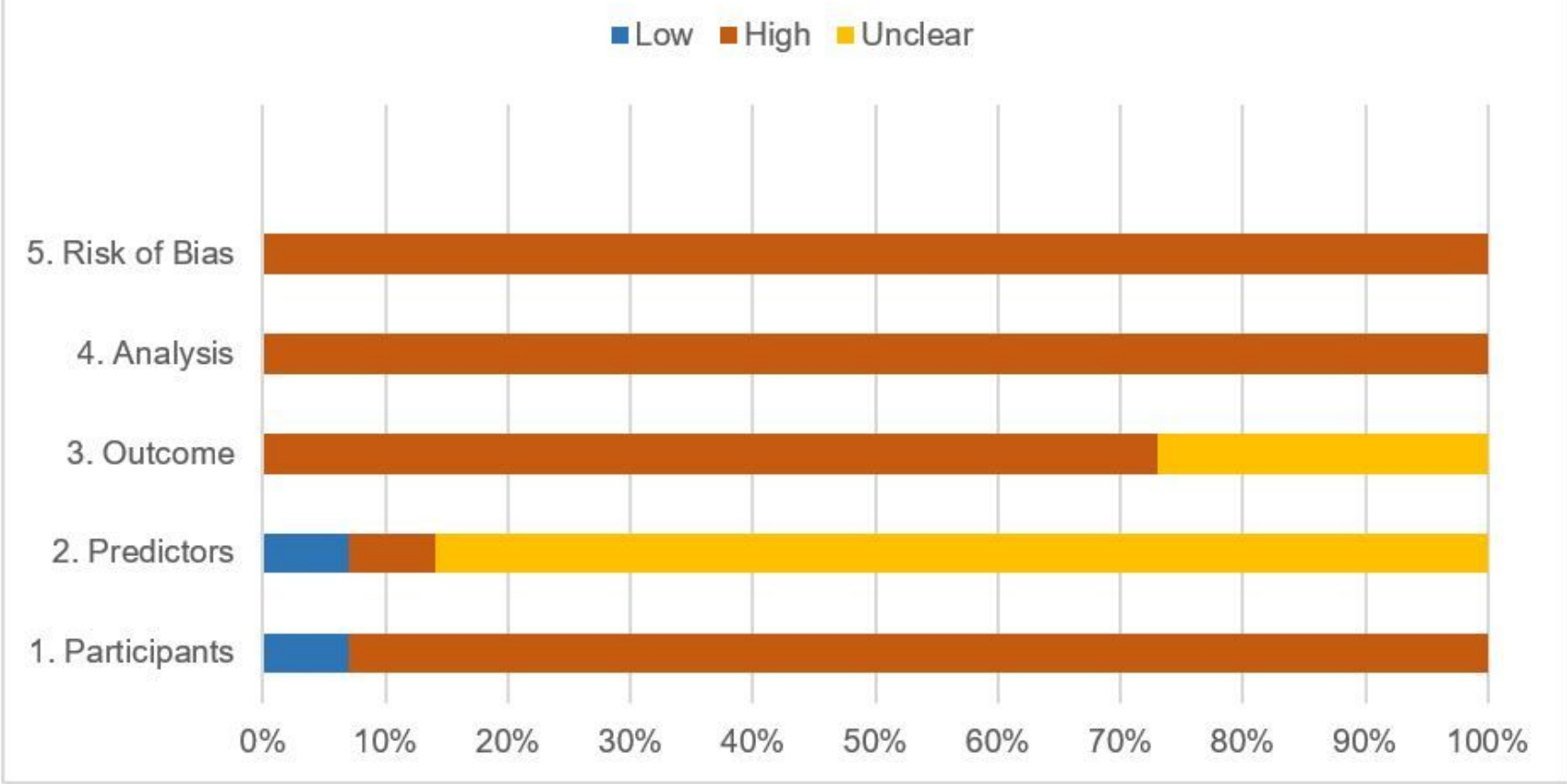

\section{Figure 1}

Percentages of the Risk of Bias of the studies according to PROBAST.

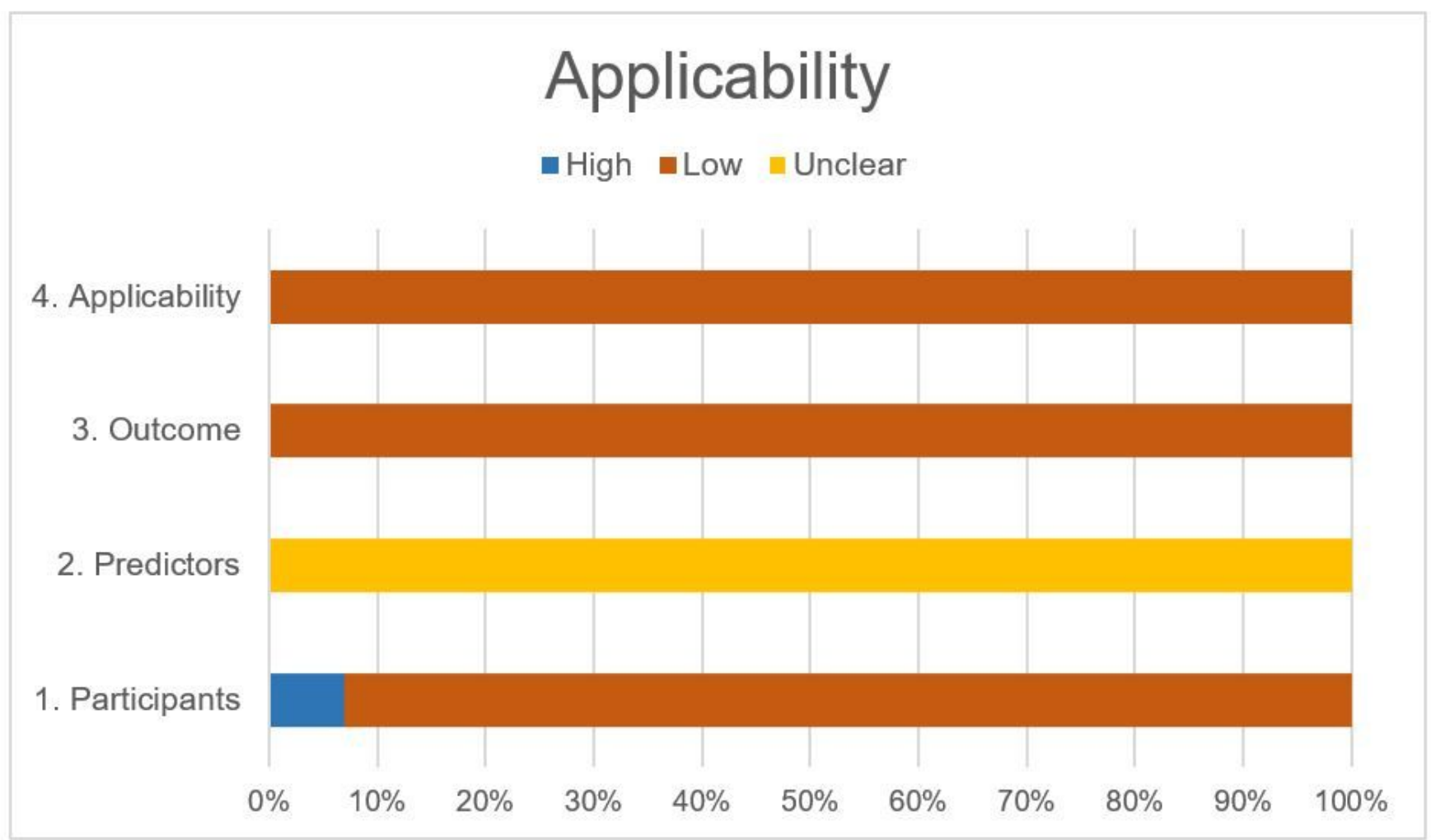

\section{Figure 2}

Percentages of the Applicability of the studies according to PROBAST. 


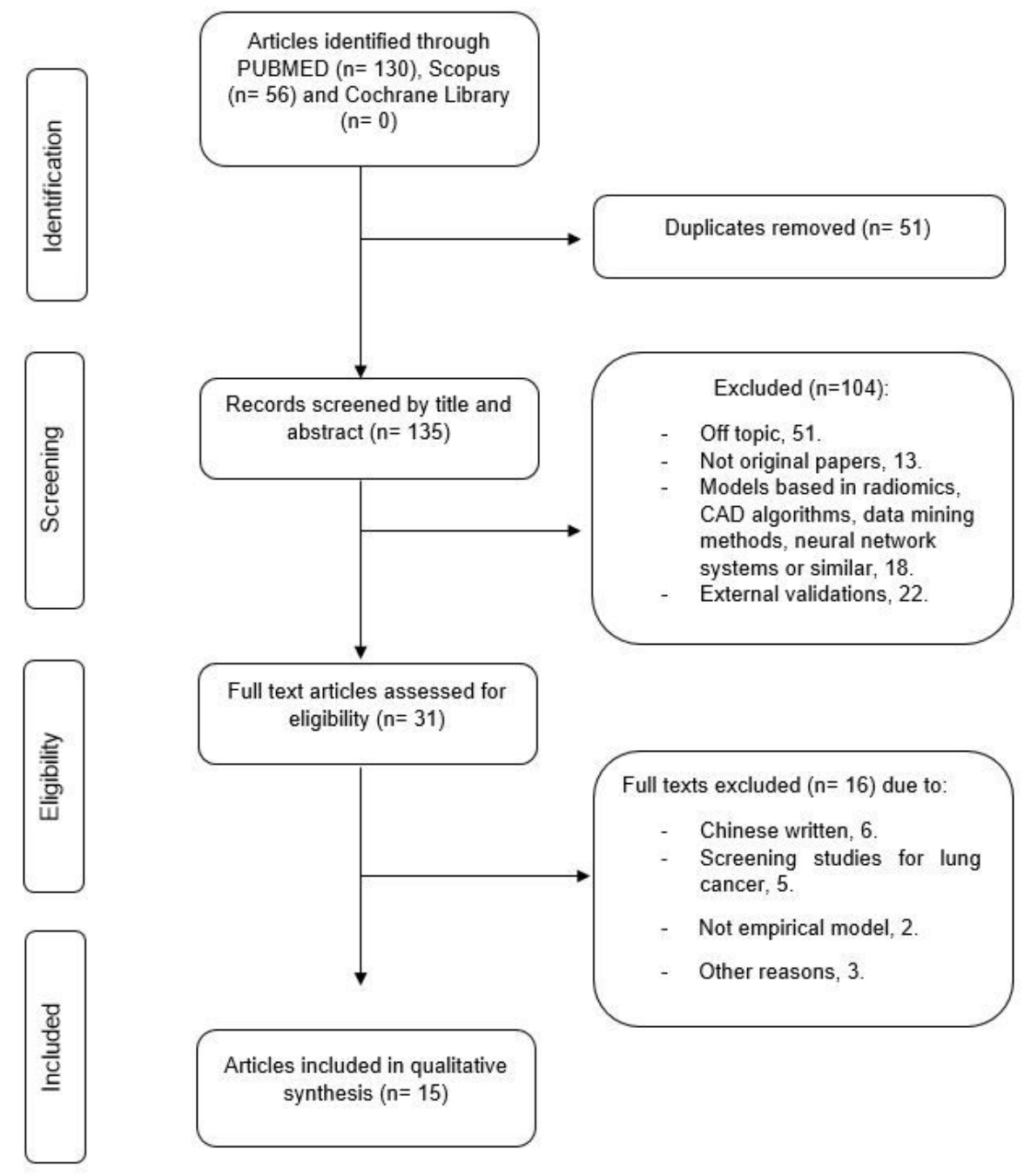

Figure 3

Flow chart outlining study selection.

\section{Supplementary Files}

This is a list of supplementary files associated with this preprint. Click to download.

- Appendix.docx

- SupplementaryMaterial.docx

- Table2.docx 